SINAI Journal of Applied Sciences

\title{
IN VITRO PROPAGATION OF HARD TO ROOT ITRANA OLIVE (Olea europea L.) CULTIVAR
}

\author{
Nada S.M. Kamil ${ }^{1 *}$; Sourour, M.M' ${ }^{1}$ M.Y.H. ABDALLA ${ }^{1}$; and M.M. Abdallah ${ }^{2}$ \\ 1. Dept. Plant Prod., Fac. Environ. Agric. Sci., Suez Canal Univ., Egypt. \\ 2. Cent. Desert Res., Shaikh Zouid, North Sinai, Egypt.
}

\section{ABSTRACT}

The olive (Olea europea L.) explants of Itrana cultivar were cultured on different types of medium i.e; Olive medium (OM), Woody Plant medium (WPM) and Murashige \& Skoog medium (MS). Also, different explant types (shoot tips and nodal cuttings) were investigated. The results showed that the Olive medium (OM) with nodal cuttings proved to be the best medium and explant for establishment of olive plants cv. Itrana. The best multiplication for cv. Itrana was obtained with culturing on OM medium supplemented $3 \mathrm{mg}^{-1}$ zeatin. Shoot elongation was carried out on OM medium containing different concentrations of Gibberellic acid $\left(\mathrm{GA}_{3}\right)$. Adding $2 \mathrm{mg} \mathrm{l}^{-1}$ of $\mathrm{GA}_{3}$ to the culture medium proved to be the best concentration for obtaining the highest shoots $(10.66 \mathrm{~cm})$. Shoot rooting was carried out on half strength OM medium with different types of auxins (IBA, NAA or IAA). IBA proved to be the most effective one for inducing rooting of shoots. Adding $3 \mathrm{mg} \mathrm{l}^{-1}$ of IBA achieved the highest number of roots $(2.66)$ and root length $(3.66 \mathrm{~cm})$ and it was proved to be the best concentration for rooting stage. Adding $0.5 \mathrm{mgl}^{-1}$ of Putrescine to the rooting medium proved to be the best concentration for root formation and growth. Finally hardening the produced plantlets were performed successfully in greenhouse in pots containing mixture of peat-moss, vermiculite and sand $(1: 1: 1) \mathrm{V} / \mathrm{V} / \mathrm{V}$.

Key words: Olea europea L., In vitro, nodal cutting, Putrescine, zeatin.

\section{INTRODUCTION}

The olive tree cultivar 'Itrana' is used for both table and oil. The fruit are roundish, asymmetrical and of medium to large size (3-5 g). At harvest the drupes are dark wine color, freckled with a whitish dusting. The oil is of good quality (average yield is 20\%) pleasing in taste and very prized. The cured olives are very much in demand. Maturation is late (November, DecemberJanuary). In vitro culture may overcome some difficulties experienced with conventional propagation techniques and offers an important way for genetic improvement in olive.

Nevertheless, biotechnological methods, such as in vitro culture, require efficient techniques and protocols of in vitro proliferation and rooting, particularly when the explants derive from mature tissues (Rugini et al. 1993).

Olive oil is used as food since prehistoric times. Olive oil not only contains oleic acid (18:1 n-9), but also contains small amounts of other fatty acids, such as palmitic, palmitoleic, stearic, linoleic, and $\alpha$-linolenic acids. In addition to fatty acids, olive oil also contains phenolic compounds. Oleic acid, a monounsaturated nonessential fatty acid, belongs to n-9 family of fatty acids.

It is found in animals and plants and represents a large proportion of human dietary intake with low uptake by liver and brain. Beef and poultry contain $30-45 \%$

\footnotetext{
* Corresponding author: Tel.: +201098415179

E-mail address: na_da448@yahoo.com
} 
oleic acid, while oils such as palm, peanut, soybean, grape seed oil, and sunflower contain $25-49 \%$ oleic acid (Waterman and Lockwood 2007).

The main objective of this study was to propagate hard to root olive cultivar namely: Itrana in vitro by using tissue culture technique and try to solve the rooting problem.

\section{MATERIALS AND METHODS}

\section{Plant Material}

This work was carried out at the Plant Tissue Culture Laboratory, Faculty of Environmental Agricultural Sciences (FEAS), El-Arish, Suez Canal University (SCU) during the period from 2012 to 2015. Plant materials were collected from olive (Olea europea L.) trees Itrana cultivar grown in the Desert Research Center in AlShaikh Zowaid, North Sinai, Governorate, Egypt. Plant material was warped with wet paper and transferred in ice box to the Tissue Culture lab.

\section{Explant Sterilization}

Stem nodal cuttings explants from olive cultivar namely: (Itrana) were subjected to running tap water then rinsed in water with two drops of tween 20 on rotary shiker for 60 minutes. To remove the remaining detergent, explants were washed with distilled water. The explants were soaked for 20 minutes in 30\% commercial bleach of (clorox) solution. Explants were soaked in ethanol alcohol $(70 \%)$ for 1 minute after they were washed with sterile water, followed by mercuric chloride solution $\left(\mathrm{HgCl}_{2}\right) 1.0 \mathrm{~g} \mathrm{l}^{-1}$ for 5 minutes. After every step explants were washed with sterilized distilled water for 3-5 times to remove all traces of the disinfectant. All steps of the sterilization had been done under aseptic conditions.

\section{Culture Medium}

Murashige and Skoog medium (MS), Woody Plant medium (WPM) and Olive medium (OM) containing macro and micro elements as well as vitamins, according to Murashige and Skoog (1962) $4.4 \mathrm{~g} \mathrm{~L}^{-1}$, Lloyd and McCown (1980) $2.58 \mathrm{gL}^{-1}$ and Olive medium (Rugini, 1984) $4.02 \mathrm{gL}^{-1}$ were investigated in this study. The media were supplemented with $3 \%$ sucrose and all media were adjusted to $\mathrm{pH}$ 5.7-5.8 before gelling with $7.50 \mathrm{gL}^{-1}$ agar.

\section{Establishment Stage}

To examine the best medium and explant type for establishment of cv. Itrana, shoot tip and nodal cuttings were cultured on three different media (MS, OM and WPM). The cultured explants were incubated under $16 \mathrm{hr}$ of artificial light and $8 \mathrm{hr}$., of dark provided by cool white fluorescent lamps (light intensity $2000 \mathrm{lux}$ ) and average of temperature degree $25 \pm 2^{\circ} \mathrm{C}$ for all experiments in all stages. The following measurements were recorded after 6 weeks on culture medium:

1. Main shoot length $(\mathrm{cm})$.

2. Number of shoots/ explant.

3. Number of leaves.

\section{Multiplication Stage}

Shoots obtained from establishment stage were cut into nodal cuttings $(2-3 \mathrm{~cm}$ long) each contained two axillary buds and cultured on $\mathrm{OM}$ medium containing zeatin at $0.0,1.0,2.0,3.0$ or $4.0 \mathrm{mgL}^{-1}$. After six weeks of subculture, (number of shoots/explant, main shoot length $(\mathrm{cm})$ and number of leaves/explant) data were recorded.

\section{Shoot Elongation}

The proliferated shoots were divided into single explants containing one or two nodes and transferred to jars containing full strength OM supplemented with different concentrations of $\mathrm{GA}_{3}(0.0,1.0,2.0,3.0$ or $\left.4.0 \mathrm{mg} \mathrm{L}^{-1}\right)$. After 6 weeks from culture data were recorded to select the best $\mathrm{GA}_{3}$ concentration which encouraged the highest shoot elongation. 


\section{Rooting Stage}

For rooting, individual shoots of 3-4 cm long which obtained from multiplication stage were excised from the proliferated and elonged shoots and cultured on half strength of OM medium supplemented with $1.0 \mathrm{mg} \mathrm{L}^{-1}$ of indole-3-butyric acid (IBA), $1.0 \mathrm{mgL}^{-1}, \quad \alpha$-naphthalene acetic acid (NAA), $1.0 \mathrm{mgL}^{-1}$ indole-3-acetic acid (IAA) and control treatment to determine the effect of auxin type on shoot rooting length and growth.

Then shoots were cultured on half strength of $\mathrm{OM}$ media with different concentration of IBA $(0.0,1.0,3.0$ and 5.0 $\left.\mathrm{mgL}^{-1}\right)$. Then different concentrations of putrescine dihydrochloride $\left(\mathrm{C}_{4} \mathrm{H}_{12} \mathrm{~N}_{4} \cdot \mathrm{HCl}\right)$ $\left(0.0,0.1\right.$ or $\left.0.5 \mathrm{mgL}^{-1}\right)$ combined with 3.00 $\mathrm{mgL}^{-1}$ IBA were used to promote explants rooting. After six weeks, number of roots/shoot, main root length $(\mathrm{cm})$, main shoot length $(\mathrm{cm})$, number of shoots/ explant and number of leaves/shoot were recorded.

\section{Acclimatization of Plantlets}

Rooted shoots obtained from rooting stage were taken away from the jars. Roots of the chosen plantlets were washed thoroughly with running water to get rid of residues. Then roots were washed well with sterilized distilled water and planted in black polyethylene pots $8 \mathrm{~cm}$ in diameter filled with peatmoss, vermiculite and sand $1: 1: 1, \quad \mathrm{~V} / \mathrm{V} / \mathrm{V}$ under greenhouse then covered with white transparent bags.

The holes were made after one week in covered bags and then we made these holes bigger each week for four weeks until the plantlet become suitable to be transferred to the bigger pots. When plantlets produced new leaves they were transferred from the green house eventually to field conditions.

\section{Statistical Analysis}

There were four replications each replicate contained 3 explants for each treatment and data were tested using a completely randomized design (CRD) by using Co-STAT software V.6.13 (Cohort software, Berkeley, CA 94701).

Differences between means were compared by using least significant range Duncan's multiple range test at $0.05 \%$ level of probability (Duncan, 1955).

\section{RESULTS AND DISCUSSION}

\section{Establishment Stage}

Effect of Medium Type on Olive Olea europeae L. cv. Itrana Shoots Proliferation during Establishment Stage

The results in Table (1) and Photo (1) illustrate that the highest value of number of shoots/explant (3.0) and number of leaves/shoots (11.0) obtained with OM medium. On the other hand, OM medium and WPM medium gave the highest values of shoot length $(5.8$ and $5.0 \mathrm{~cm})$, respectively.

The lowest values were noticed with other treatments. The results of this study are in line with those of Niaz et al. 2014; Antonopoulou et al. 2012; Rkhis et al. 2011 and Brito et al. 2003. They found that olive medium (OM) proved to be suitable one, for inducing olive shoot proliferation.

Effect of Explant Type on Olive Olea europeae L. cv. Itrana Shoots Proliferation during Establishment Stage

The results in Table (2) declare that the highest value of number of shoots/ explant, number of leaves/ shoots and shoot length were obtained with nodal cutting explants. While, the lowest values were noticed with shoot tip explants. The superiority of stem nodal cutting was obtained by Rkhis et al. 2012 and Antonopoulou et al. 2011 they found that specifically, the bi-nodal explants without leaves had the highest proliferation rate and the longest new shoots of olive explants. On the other hand, the young shoot tip died. 
Table (1): Effect of medium type on shoot proliferation and growth of Itrana olive cultivar explants during establishment stage.

\begin{tabular}{cccc}
\hline Medium type & No. shoots/ explant & No. leaves/ shoot & Main shoot length (cm) \\
\hline MS & $1.00^{\mathrm{b}}$ & $7.33^{\mathrm{bc}}$ & $3.16^{\mathrm{b}}$ \\
WPM & $1.00^{\mathrm{b}}$ & $6.66^{\mathrm{bc}}$ & $5.00^{\mathrm{ab}}$ \\
OM & $3.00^{\mathrm{a}}$ & $10.66^{\mathrm{a}}$ & $5.80^{\mathrm{a}}$ \\
\hline
\end{tabular}

Means followed by the same alphabetical letter (s) within each column are not significantly different at $5 \%$ level according to Duncan's multiple range test.
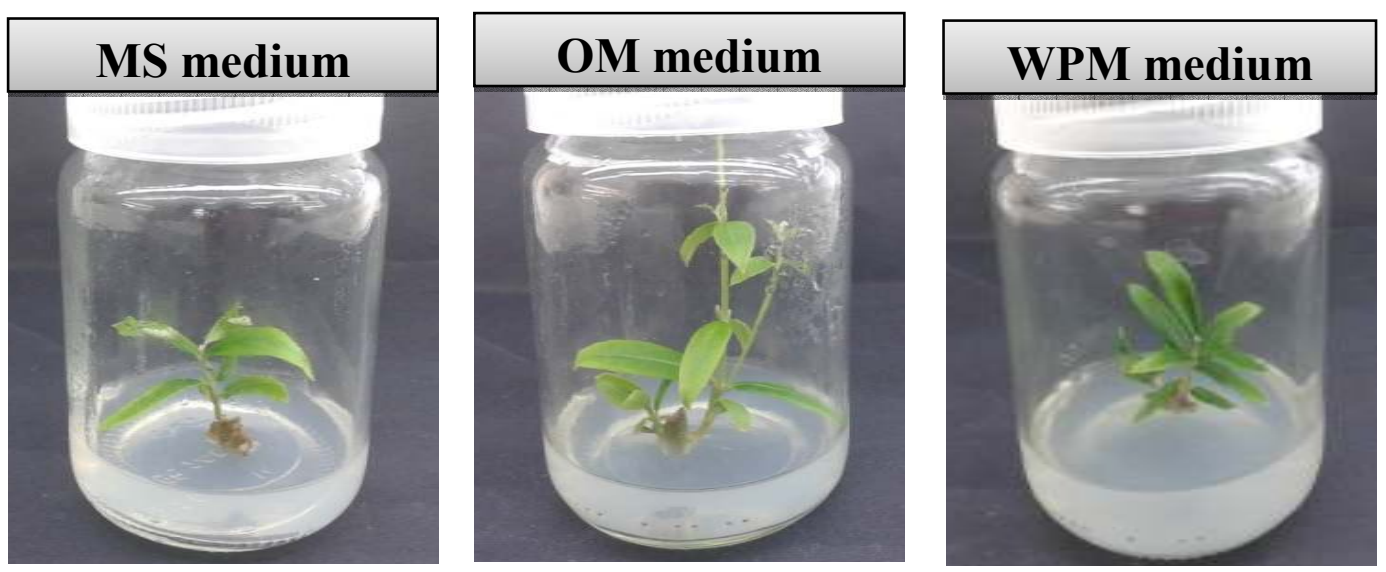

Photo (1): Effect of medium type on explant development of olive cv. Itrana during establishment stage.

Table (2): Effect of explant type on shoot proliferation and growth of Itrana olive cultivar during establishment stage.

\begin{tabular}{cccc}
\hline Explant type & $\begin{array}{c}\text { No. } \\
\text { shoots/ explant }\end{array}$ & No. leaves/ shoot & Main shoot length (cm) \\
Shoot tip & $1.00^{\mathrm{b}}$ & $1.00^{\mathrm{b}}$ & $1.00^{\mathrm{b}}$ \\
Nodal cuttings & $3.00^{\mathrm{a}}$ & $10.66^{\mathrm{a}}$ & $6.5^{\mathrm{a}}$ \\
\hline
\end{tabular}

Means followed by the same alphabetical letter (s) within each column are not significantly different at $5 \%$ level according to Duncan's multiple range test. 


\section{Multiplication Stage}

\section{Effect of Different Zeatin Concentrations on Olive Olea europeae L. cv. Itrana shoots Proliferation during Multiplication Stage}

The results in Table (3) and Photo (2) demonstrate that there were no significant differences between treatments concerning number of shoots/explant. While, the lowest value (4.66) was noticed with control treatment. Results also proved that the highest shoot length was occurred with 1 $\mathrm{mgL}^{-1} \mathrm{Zn}$. While, the lowest value was noticed with control treatment. Those results generally, agreed with those mentioned by Gozza et al. (1997), Khosrowchahi et al. (2002), Khosrowchahi et al. (2002), Mucheli et al. (2010) and Rkhis et al. (2011), reported that the highest number of leaves and buds of olive shoots were obtained in the response of $2 \mathrm{mgL}^{-1}$ of Zeatin. While, Niaz et al. (2014) observed that Zeatin $\left(3.0 \mathrm{mgL}^{-1}\right)$ blended with 0.5 $\mathrm{mgL}^{-1} 6$-Benzylaminopurine (BAP) produced the maximum number $(0.84)$ of micro shoots per explant, with shoot length of $(2.25 \mathrm{~cm})$ and $(1.88)$ node. Adding zeatin to the culture medium, significantly increase number of leaves/shoot without significant differences between all investigated concentrations.

\section{Elongation Stage}

Effect of $\mathrm{GA}_{3}$ Concentration on Olive Olea europeae L. cv. Itrana Shoots Elongation during Elongation Stage

Data in Table 4 and Photo 3 show that the highest shoot number/explant (3.33) was recorded with $3 \mathrm{mgL}^{-1} \mathrm{GA}_{3}$. The highest value of number of leaves/explant (20.66) was observed with $2 \mathrm{mgL}^{-1} \mathrm{GA}_{3}$. The highest value of shoot length (10.66) was noted with Itrana cultivar by using $2 \mathrm{mgL}^{-1} \mathrm{GA}_{3}$.

\section{Rooting Stage}

Effect of Auxin Types on Olive Olea europeae L. cv. Itrana Shoots Rooting during Rooting Stage

Data in Table (5) illustrate that number of shoots/ explant did not affected significantly by supplementation the medium with 1.0 $\mathrm{mgL}^{-1}$ of IBA. IBA gave the highest values of number of leaves/ shoot (26.66), shoot length $(13.66 \mathrm{~cm})$, number of roots/shoot (3) and root length $(7.66 \mathrm{~cm})$. These results are in agreement with Charbaji et al. (2008), Ali et al. (2009), Peyvandi et al. (2009), Rkhis et al. (2011), Rostami et al. (2012), Mangal et al. (2014) and Niaz et al. (2014) they observed that the IBA proved to be better rooting growth regulator for olive in terms of its rooting percentage, root length and number of roots per rooted explants as compared to NAA which is less efficient for rooting of olive because of being more stable in nature in comparison with IBA.

On the other hand (Yakoup et al., 2007; Lu et al., 2011; Leva, 2011) reported that after an elongation phase, medium supplemented with different concentrations of NAA gave the highest rooted of olive explants.

Effect of IBA Concentration on Olive Olea europeae L. cv. Itrana Shoots Rooting during Rooting Stage

It is clear from Table (6) and Photo 4 that there were no significant differences between treatments concerning number of shoots/explant and number of leaves/ shoot. For shoot length, the highest value (8.66 $\mathrm{cm})$ was achieved with control treatment without significant differences between IBA concentrations.

It could be observed that $3 \mathrm{mgL}^{-1}$ IBA was more effective on number of roots and root length than other treatments concerning the number of roots/ shoot and root length. The same finding was obtained by Otero and Docamp (1996) found that $70 \%$ of the olive shoots rooted in $\mathrm{OM}+3 \mathrm{mgL}^{-1}$ IBA. However, Charbaji et al. (2008) they indicated that the highest percentage of in vitro olive rooting was observed on medium containing $5 \mathrm{mgL}^{-1}$ IBA.

Application of IBA at $3 \mathrm{mgL}^{-1}$ may have triggered the early anticlinal cell division and root primordial than NAA and IAA. Sabatini et al. (1999) reported that differentiation of 
Table (3): Effect of zeatin concentration on shoot multiplication and growth of Itrana olive cultivar explants during multiplication stage.

\begin{tabular}{cccc}
\hline $\begin{array}{c}\text { Zeatin concentration } \\
\left(\mathbf{m g ~ L}^{-\mathbf{1}}\right)\end{array}$ & $\begin{array}{c}\text { No. } \\
\text { Shoots/explant }\end{array}$ & $\begin{array}{c}\text { No. } \\
\text { leaves } / \text { shoots }\end{array}$ & $\begin{array}{c}\text { Main shoot length } \\
(\mathbf{c m})\end{array}$ \\
\hline Control & $1.00^{\mathrm{a}}$ & $4.66^{\mathrm{c}}$ & $2.00^{\mathrm{d}}$ \\
1.00 & $1.00^{\mathrm{a}}$ & $10.00^{\mathrm{ac}}$ & $5.00^{\mathrm{a}}$ \\
2.00 & $1.33^{\mathrm{a}}$ & $13.00^{\mathrm{a}}$ & $3.33^{\mathrm{bc}}$ \\
3.00 & $1.00^{\mathrm{a}}$ & $10.00^{\mathrm{ac}}$ & $2.16^{\mathrm{cd}}$ \\
4.00 & $1.33^{\mathrm{a}}$ & $11.33^{\mathrm{ab}}$ & $4.33^{\mathrm{ab}}$ \\
\hline
\end{tabular}

Means followed by the same alphabetical letter (s) within each column are not significantly different at $1 \%$ level according to Duncan's Multiple Range Test.

Table (4): Effect of $\mathrm{GA}_{3}$ concentrations on shoot elongation of Itrana olive cultivar explants during elongation stage.

\begin{tabular}{cccc}
\hline $\begin{array}{c}\mathbf{G A}_{3} \text { concentration } \\
\left(\mathbf{m g L}^{-1}\right)\end{array}$ & $\begin{array}{c}\text { No. shoots/ } \\
\text { explant }\end{array}$ & $\begin{array}{c}\text { No. leaves/ } \\
\text { shoot }\end{array}$ & $\begin{array}{c}\text { Main shoot length } \\
(\mathbf{c m})\end{array}$ \\
\hline Control & $1.00^{\mathrm{d}}$ & $4.66^{\mathrm{d}}$ & $2.66^{\mathrm{ef}}$ \\
1.00 & $2.33^{\mathrm{b}}$ & $15.33^{\mathrm{b}}$ & $3.33^{\mathrm{de}}$ \\
2.00 & $3.33^{\mathrm{a}}$ & $20.66^{\mathrm{a}}$ & $10.66^{\mathrm{a}}$ \\
3.00 & $1.66^{\mathrm{c}}$ & $14.66^{\mathrm{b}}$ & $4.83^{\mathrm{b}}$ \\
4.00 & $1.00^{\mathrm{d}}$ & $7.33^{\mathrm{d}}$ & $2.33^{\mathrm{f}}$
\end{tabular}

Means followed by the same alphabetical letter (s) within each column are not significantly different at $5 \%$ level according to Duncan's multiple range test.

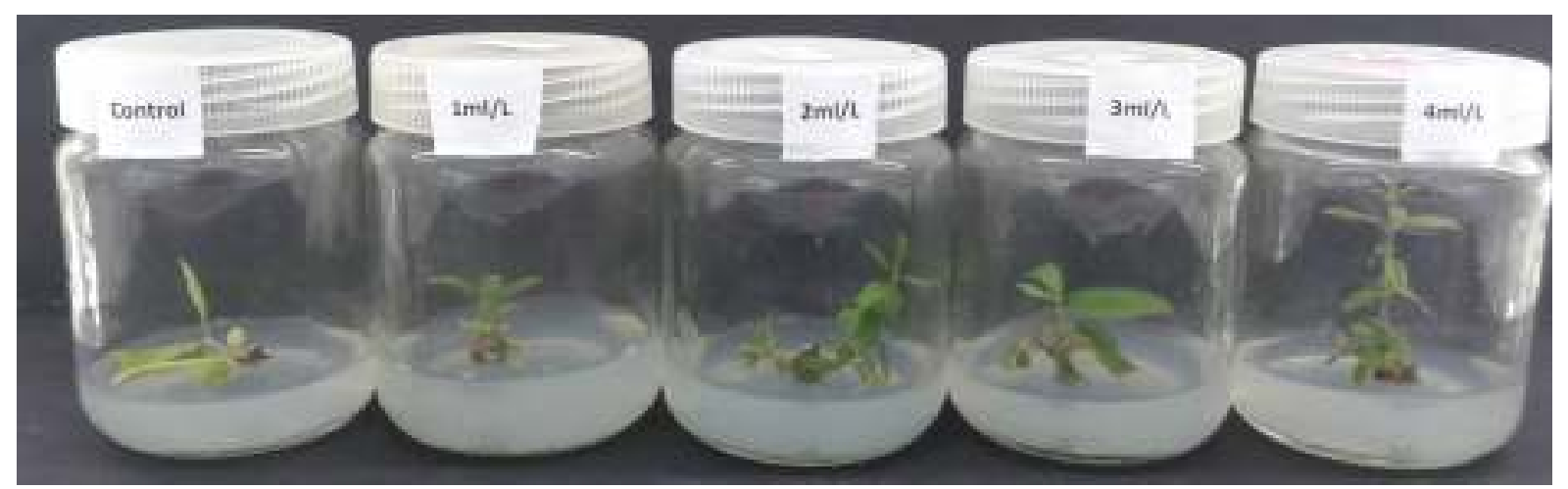

Photo (2): Effect of Zeatin concentration on explant development of olive cv. Itrana during multiplication stage. 


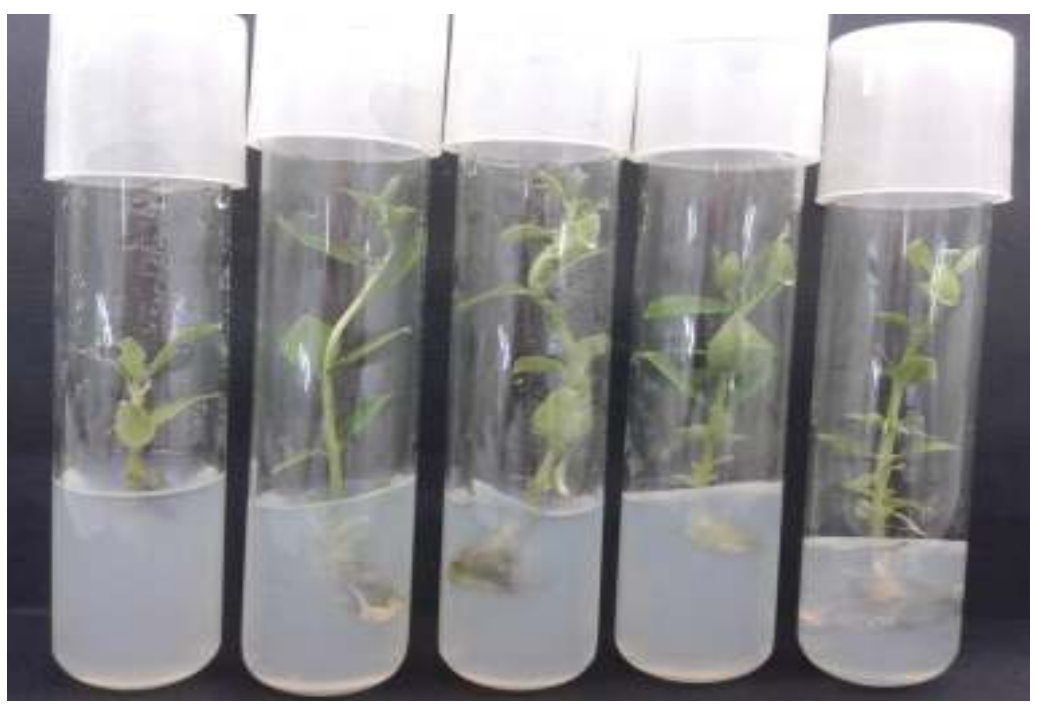

Photo (3): Effect of $2 \mathrm{mgL}^{-1} \mathrm{GA}_{3}$ concentrations on shoot elongation of olive cv. Itrana during elongation stage.

Table (5): Effect of auxin type on Itrana olive cultivar explants during rooting stage.

\begin{tabular}{cccccc}
\hline Auxin type & $\begin{array}{c}\text { No. shoots/ } \\
\text { explant }\end{array}$ & $\begin{array}{c}\text { No. } \\
\text { leaves/ shoot }\end{array}$ & $\begin{array}{c}\text { Main shoot length } \\
(\mathbf{c m})\end{array}$ & $\begin{array}{c}\text { No. roots/ } \\
\text { shoot }\end{array}$ & $\begin{array}{c}\text { Main root } \\
\text { length (cm) }\end{array}$ \\
\hline Control & $1.33^{\mathrm{ab}}$ & $12.00^{\mathrm{bc}}$ & $8.66^{\mathrm{b}}$ & $1.00^{\mathrm{b}}$ & $1.00^{\mathrm{b}}$ \\
IBA & $3.00^{\mathrm{a}}$ & $26.66^{\mathrm{a}}$ & $13.66^{\mathrm{a}}$ & $3.00^{\mathrm{a}}$ & $7.66^{\mathrm{a}}$ \\
NAA & $2.00^{\mathrm{ab}}$ & $7.33^{\mathrm{c}}$ & $2.50^{\mathrm{c}}$ & $1.00^{\mathrm{b}}$ & $1.00^{\mathrm{b}}$ \\
IAA & $2.00^{\mathrm{ab}}$ & $16.00^{\mathrm{abc}}$ & $5.00^{\mathrm{c}}$ & $1.00^{\mathrm{b}}$ & $1.00^{\mathrm{b}}$
\end{tabular}

Means followed by the same alphabetical letter (s) within each column are not significantly different at 5\% level according to Duncan's multiple range test.

Table (6): Effect of IBA concentrations on Itrana olive cultivar explants during rooting stage.

\begin{tabular}{cccccc}
\hline $\begin{array}{c}\text { IBA concentration } \\
\left(\mathbf{m g L}^{-1}\right)\end{array}$ & $\begin{array}{c}\text { No. Shoots/ } \\
\text { explant }\end{array}$ & $\begin{array}{c}\text { No. leaves/ } \\
\text { shoot }\end{array}$ & $\begin{array}{c}\text { Main shoot } \\
\text { length }(\mathbf{c m})\end{array}$ & $\begin{array}{c}\text { No. roots/ } \\
\text { shoot }\end{array}$ & $\begin{array}{c}\text { Main root } \\
\text { length }(\mathbf{c m})\end{array}$ \\
\hline Control & $1.33^{\mathrm{a}}$ & $12.00^{\mathrm{ab}}$ & $8.66^{\mathrm{a}}$ & $1.00^{\mathrm{b}}$ & $1.00^{\mathrm{b}}$ \\
1.00 & $1.00^{\mathrm{a}}$ & $10.66^{\mathrm{bc}}$ & $2.83^{\mathrm{bc}}$ & $1.00^{\mathrm{b}}$ & $1.66^{\mathrm{b}}$ \\
3.00 & $1.00^{\mathrm{a}}$ & $11.33^{\mathrm{ab}}$ & $2.66^{\mathrm{bc}}$ & $2.66^{\mathrm{a}}$ & $3.66^{\mathrm{a}}$ \\
5.00 & $1.00^{\mathrm{a}}$ & $9.33^{\mathrm{bc}}$ & $2.33^{\mathrm{c}}$ & $1.00^{\mathrm{b}}$ & $1.00^{\mathrm{b}}$ \\
\hline
\end{tabular}

Means followed by the same alphabetical letter (s) within each column are not significantly different at 5\% level according to Duncan's multiple range test. 
phloem ray parenchyma cells into root primordial depends upon the type and concentration of auxin.

Effect of Putrescine Concentrations on Olive Olea europeae L. cv. Itrana Shoots Rooting during Rooting Stage

Data in Table (6) show that there were no significant differences between both treatments concerning number of shoots/ explant. The best values of number of leaves/ shoot, shoot length, number of roots and root length were belonged to $0.5 \mathrm{mg} \mathrm{l}^{-1}$ of putrescine. Similarly (Rugini et al., 1993; Briccoli and Lombardo, 1996; Bati et al. 2006) found that rooting of olive shoots was best in the above modified OM medium supplemented with different concentrations of puterscine.

Table (7): Effect of putrescine concentrations on Itrana olive cultivar explants during rooting stage.

\begin{tabular}{cccccc}
\hline $\begin{array}{c}\text { Putrescine concentration } \\
\left(\mathbf{m g L}^{-1}\right)\end{array}$ & $\begin{array}{c}\text { No. shoots/ } \\
\text { explant }\end{array}$ & $\begin{array}{c}\text { No. leaves/ } \\
\text { shoot }\end{array}$ & $\begin{array}{l}\text { Main shoot No. roots/ Main shoot } \\
\text { length }(\mathbf{c m})\end{array}$ & $\begin{array}{c}\text { shoot } \\
\text { length }(\mathbf{c m})\end{array}$ \\
\hline 0.1 & $1.00^{\mathrm{a}}$ & $9.33^{\mathrm{b}}$ & $2.33^{\mathrm{c}}$ & $1.00^{\mathrm{b}}$ & $1.00^{\mathrm{c}}$ \\
0.5 & $3.00^{\mathrm{a}}$ & $16.66^{\mathrm{a}}$ & $11.33^{\mathrm{a}}$ & $3.00^{\mathrm{a}}$ & $7.66^{\mathrm{a}}$ \\
\hline
\end{tabular}

Means followed by the same alphabetical letter (s) within each column are not significantly different at 5\% level according to Duncan's multiple range test.
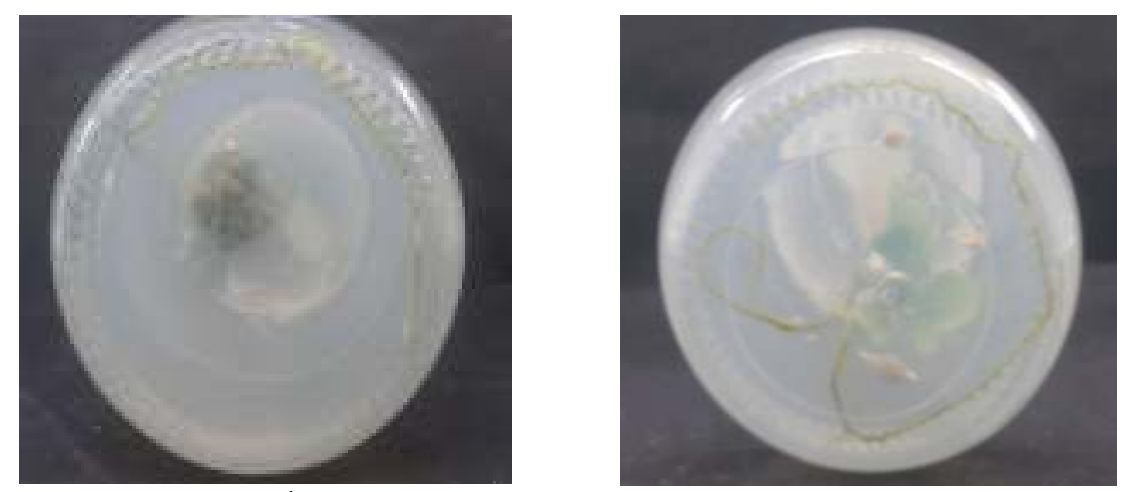

Photo (4): Effect of $3 \mathrm{mgL}^{-1}$ IBA with $0.5 \mathrm{mgl}-1$ Putrescine on shoot rooting of olive cv. Itrana during rooting stage.

\section{REFERENCES}

Antonopoulou, C.; Dimassi, K.; Chatzissavvidis, C.; Papadakis, I. and Therios, I. (2012). The effect of explant type and nutrient medium on the in vitro proliferation of olive Olea europea L. 'Chondrolia chalkidiki'. Acta Hort., 949: 185-189.

Ali, A.; Ahmad, T.; Abbasi, N.A. and Hafiz, I.A. (2009). Effect of different media and growth regulators on in vitro shoot proliferation of olive cultivar 'Moraiolo'. Pak. J. Bot., 41: 783-795.

Bati, C.C.; Godino, G.; Monardo, D. and Nuzzo, V. (2006). Influence of propagation techniques on growth and yield of olive trees cultivars 'Carolea' and 'Nocellara' Etnea. Scientia Hort., 190: 173-182.

Brito, G.; Costa, A.; Fonseca, H.A. and Santos, C.V. (2003). Response of Olea europea spp. maderensis in vitro shoots 
exposed to osmotic stress. Scientia Hort., 97: 411-417.

Briccoli, B.C. and Lombardo, N. (1996). In vitro propagation of $\mathrm{cv}$. Nocellara Etnea, Atti del convengo. L'olivicoltura mediterannea:Stato e prospettive della coltura e della ricerca Renda (cs), Italy 26: 249-257.

Charbaji, T.; Ayyoubi, Z. and Karajouli, I. (2008). In vitro propagation of some Syrian varieties of olive (Olea europeae L.). Acta Agronomica Hungarica, 56: 107-111.

Cohort software, PO Box 1149, Berkeley, CA 94701, USA.

Duncan, D.B. (1975). T-tests and intervals for comparisons suggested by the data. Biometrics. 31: 339-59.

Gozza, R.; Turco, D.; Bati, C.B. and Bitonti, M.B. (1955). Influence of growth medium on mineral composition and leaf histology in micropropagated plantlets of Olea europaeae L. Plant Cell, Tissue and Organ Culture, 51 : 215-223.

Khosrowchahi, M.; Aidinlou, P.V.; Pour, M.A.; Moghoddam, M. and Bakhsh, M.A. (2002). In vitro shoot proliferation of Olea europeae L. cv. Dezfouly. Agric Sc., (Tabriz). 3: 39-46.

Leva, A. (2011). Innovative protocol for" "ex vitro rooting" on olive micropropagation. Cent. Eur. J. Biol., 6: 352-358.

Lloyd, G. and McCown, B. (1980). Commercially feasible micropropagation of mountain laurel, Kalmia latifolia, by use of shoot tip culture. Comb proc int plant prop Soc., 30: 421-427.

Lu, S.C.; Qui, Z.J.; Jie, L. and Hongxia, Z. (2011). An efficient method for adventitious shoot regeneration from leaf and stem segment explants of Russian olive Elaeagnus and gustifolia L. China Biotechnol., 31: 113-118.
Mangal, M.; Sharma, D.; Sharma, M. and Kumar, S. (2014). In vitro regeneration in Olive (Olea europea L.) cv. 'Frontio' from nodal segments. Indian J. Experimental Biol., 52: 912-916.

Mucheli, M.; Standardi, A.; El-Behi, A.W.; Zakhour, D. and Yasin, M. (2010). In vitro proliferation of olive (Dolce Agogia and Moraiolo): effect of different cytokinins. Acta Hort., 884: 587-590.

Murashige, T. and Skoog, F. (1962). A revised medium for rapid growth and bioassays with tobacco tissue cultures. Physiol. Plant, 15: 473-497.

Niaz, N.; Ullah, S.; Ullah, M. and Jabeen, N. (2014). Effect of growth regulators on micropropagation of different olive cultivars (Olea europeae L.). Sci. Letters, 2: 48-52.

Otero, L. and Docamp, D. (1996). Micropropagation of olive (Olea europeae L.) cv.clone oblonga by in vitro embryo culture. Phyton (Buenos Aires), 59: 201-206.

Peyvandi, M.; Farahani, F.; Noormohamadi, Z.; Hosseini, M.; Banihashemi, O. and Ataea, S. (2009). Mass production of Olea europeae L. (cv.Rowghani) through micropropagation. General and Appl. Plant Physiol., 35: 35-43.

Rostami, A.A. and Shahsavar, A.R. (2012). In vitro Micropropagation of Olive (Olea europeae L.) 'Mission' by Nodal Segments. J. Biol. Environ. Sc., 6 (17): 155-159.

Rkhis, A.C.; Maalej, M.; Drira, N. and Standardi, A. (2011). Micropropagation of olive tree Olea europea L. 'Queslati'. Turk J. Agric., 35: 403-412.

Rugini, E.; Jacoboni, A. and Luppino, M. (1993). Role of basal shoot darkening and exogenous putrescine treatments on in vitro rooting and on endogenous 
polyamine changes in difficult-to-root woody species. Scientia Hort., 53: 63-72.

Rugini, E.; Bazzoffia, A.; Sabatini, S.; Beis, D. and Wolkenfelt, H. (1999). An auxin dependent distal organizer of pattern and polarity in the Arabidopsis root. Scient. Hort., 99: 463-472.
Waterman, E. and Lockwood B. (2007). Active components and clinical applications of olive oil. Alternative Medicine Review, 12: 331-342.

Yakoub, B.S.; Cherifi, D. and Bonaly, J. (2007). Optimization of the production of in vitro plants of Olea eurpeae L. var. chemlal. Cahiers Agric., 16:125-127.

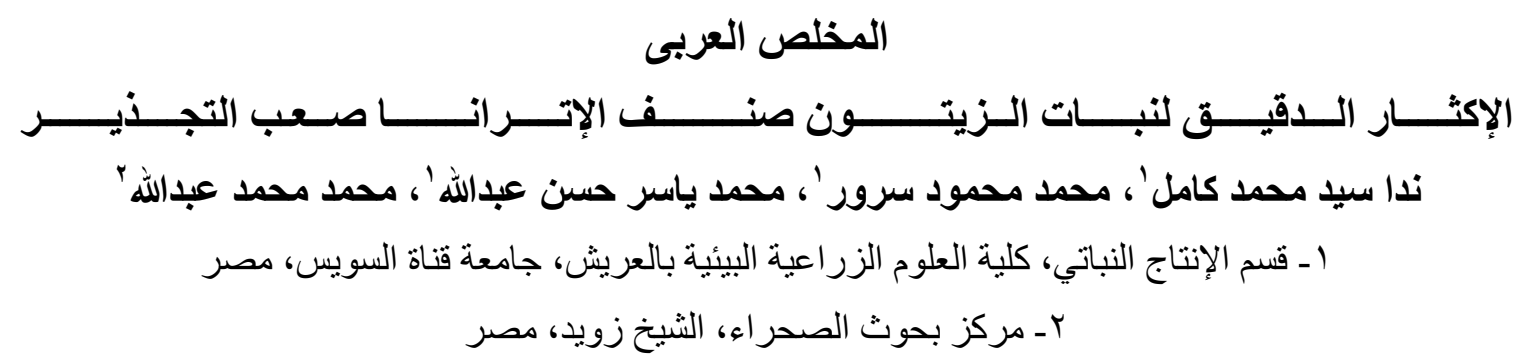

أجريت هذه الدراسة في معمل زر اعة الأنسجة النباتية ـ كلية العلوم الزر اعبة البيئية بالعريش - جامعة قناة السويس

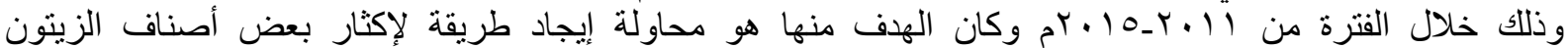
(Olea europea L.)

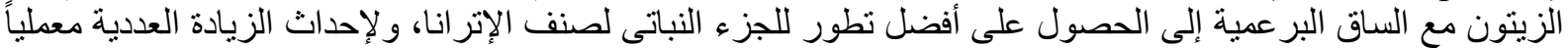

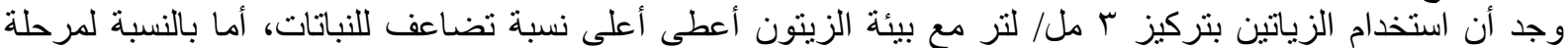

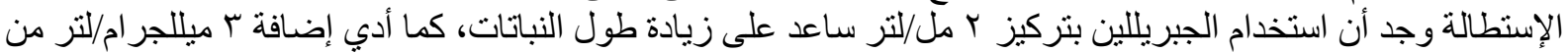

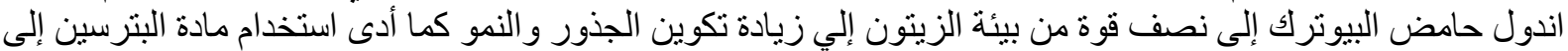

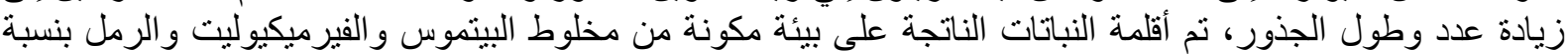
$.1: 1: 1$ الكلمات الإسترشادية: الزينون، زر اعة الأنسجة، الساق البر عمية، البترسين وزياتينز. 